\title{
Integrative taxonomy of the freshwater harpacticoid Attheyella crassa G.O. Sars, 1863 (Crustacea: Copepoda: Canthocamptidae) in the Palearctic region
}

\begin{abstract}
Elena S. Kochanova ${ }^{1,2}$, Santiago Gaviria ${ }^{3}$
${ }^{1}$ Institute of Biology of Komi Scientific Centre of the Ural Branch of the Russian Academy of Sciences, Kommunisticheskaya 28, Syktyvkar, 167982, Russia.

${ }^{2}$ Zoological Institute of Russian Academy of Sciences, University Embankment 1, Saint Petersburg, 199034, Russia.E-mail: Kochanova91@gmail.com

${ }^{3}$ University of Vienna, Department of Limnology and Bio-Oceanography \& Technisches Büro für Biologie, Fred-Raymond-Gasse 19/2/4, A-1220 Vienna, Austria. E-mail: santiago.gaviria@gmx.at

ABSTRACT: The phylogenetic structure of the freshwater harpacticoid copepod Attheyella crassa G.O. Sars, 1863 was studied. This species is wide-spread in Europe and European Russia. Genetic and morphological divergence of populations from distant localities were analyzed. The most variable morphological characters, as well as genetic diversity among ten Western Palearctic populations, were revealed.

How to cite this article: Kochanova E.S., Gaviria S. 2018. Integrative taxonomy of the freshwater harpacticoid Attheyella crassa G.O. Sars, 1863 (Crustacea: Copepoda: Canthocamptidae) in the Palearctic region // Invert. Zool. Vol.15. No.3. P.267-276. doi: 10.15298/ invertzool.15.3.05
\end{abstract}

KEY WORDS: morphology, systematics, phylogenetics, phylogeography, meiofauna.

\section{Интегративная таксономия пресноводной гарпактициды Attheyella crassa G.O. Sars, 1863 (Crustacea: Copepoda: Canthocamptidae) в Палеарктике}

\footnotetext{
Е.С. Кочанова ${ }^{1,2}$, С. Гавирия ${ }^{3}$

${ }^{1}$ Институт биологии Коми Научного Центра Уральского Отделения Российской академии наук, ул. Коммунистическая, 28, Сыктывкар 167982, Россия.

2 Зоологический институт Российской академии наук, Университетская наб. 1, СанктПетербург, 199034, Россия. E-mail: Kochanova91@gmail.com

${ }^{3}$ University of Vienna, Department of Limnology and Bio-Oceanography \& Technisches Bbro fbr Biologie, Fred-Raymond-Gasse 19/2/4, A-1220 Vienna, Austria. E-mail: santiago.gaviria@gmx.at

РЕЗЮМЕ: В данной работе проведены филогенетические исследования широко распространенного в Европе и европейской части России вида пресноводной гарпактициды Attheyella crassa G.O. Sars, 1863. Выявлены морфологические и молекулярно-генетические различия между географически изолированными популяциями. В результате представлены наиболее изменчивые морфологические признаки и уровень генетической дивергенции среди десяти популяций вида в Западной Палеарктике.
} 
Как цитировать эту статью: Kochanova E.S., Gaviria S. 2018. Integrative taxonomy of the freshwater harpacticoid Attheyella crassa G.O. Sars, 1863 (Crustacea: Copepoda: Canthocamptidae) in the Palearctic region // Invert. Zool. Vol.15. No.3. P.267-276. doi: 10.15298/invertzool.15.3.05

КЛЮЧЕВЫЕ СЛОВА: морфология, систематика, филогенетика, филогеография, мейофауна.

\section{Introduction}

Harpacticoids are a group of copepods with high morphological diversity and species richness (Borutzky, 1952, 1964). Some studies, focused on harpacticoid taxonomy and phylogeny, have revealed a significant heterogeneity among the populations of different species (depending on geographical location and environmental conditions) and have demonstrated the presence of several complexes of cryptic species and forms (Wells, 2007; Garlitzka et al., 2012; Karanovic, McRae, 2013; Huys et al., 2016; Kochanova et al., 2018). However, the systematics and ecology of freshwater harpacticoid copepods are not well studied yet and are based mainly on morphological descriptions (Dussart, 1967; Wells, 2007) and on investigations published in the middle of the last century (Lang, 1948; Borutzky, 1952, 1964). The integrative approach including morphological and genetic studies, allows to investigate the population structure of a species, its biogeography and possible patterns of distribution (Dayrat, 2005). Moreover, the study of morphological and genetic variation helps to elucidate the processes that create and maintain diversity (Masta, Maddison, 2002; Garcia-Paris et al., 2003).

The copepod Attheyella crassa Sars, 1863 belongs to the family Canthocamptidae, the most species-rich family of the order Harpacticoida (Gaviria, Defaye, 2015; Walter, Boxshall, 2018). The species shows a Palearctic distribution and is widespread in Europe and Russia (from Pskov region to Carelian Isthmus) in different types of water bodies (Enckell, 1980; Defaye, Dussart, 2011). Due to the resis- tance of $A$. crassa to various organic and inorganic compounds, as well as its relatively short period of development (4-6 weeks), this species was used in toxicological studies (Turesson et al., 2007; Gardeström et al., 2008). The latter studies showed that due to the exposure to toxic substances, body length and individual fertility may change, as well as the genetic diversity, which decreases significantly in affected populations.

In order to study systematics (taxonomy and phylogeny) of the freshwater harpacticoid copepod A. crassa, morphological and genetic variability among different European and Russian populations of the species were analysed.

\section{Material and Methods}

Samples were collected from ten different freshwater habitats (Fig. 1) using a 100- $\mu \mathrm{m}$ mesh size hand net. Living (non-fixed) samples were sorted under a stereomicroscope Micromed (China), harpacticoids were individually preserved in $96 \%$ ethanol. In order to analyze morphological characters, 98 adult females of A. crassa from eight different populations were measured (Table 1). The identification and measurements of the species were done under a microscope Leica DM 4000B (Germany). Body length of these specimens was measured from the tip of prosome to the distal end of the caudal rami in dorsal position. More than 20 quantitative morphological and morphometric characters, important for diagnostic identification, were considered. The statistical variability of characters was assessed with help of the KruskalWallis test (each character was compared among all populations) and of the Kolmogorov-Smirnov 


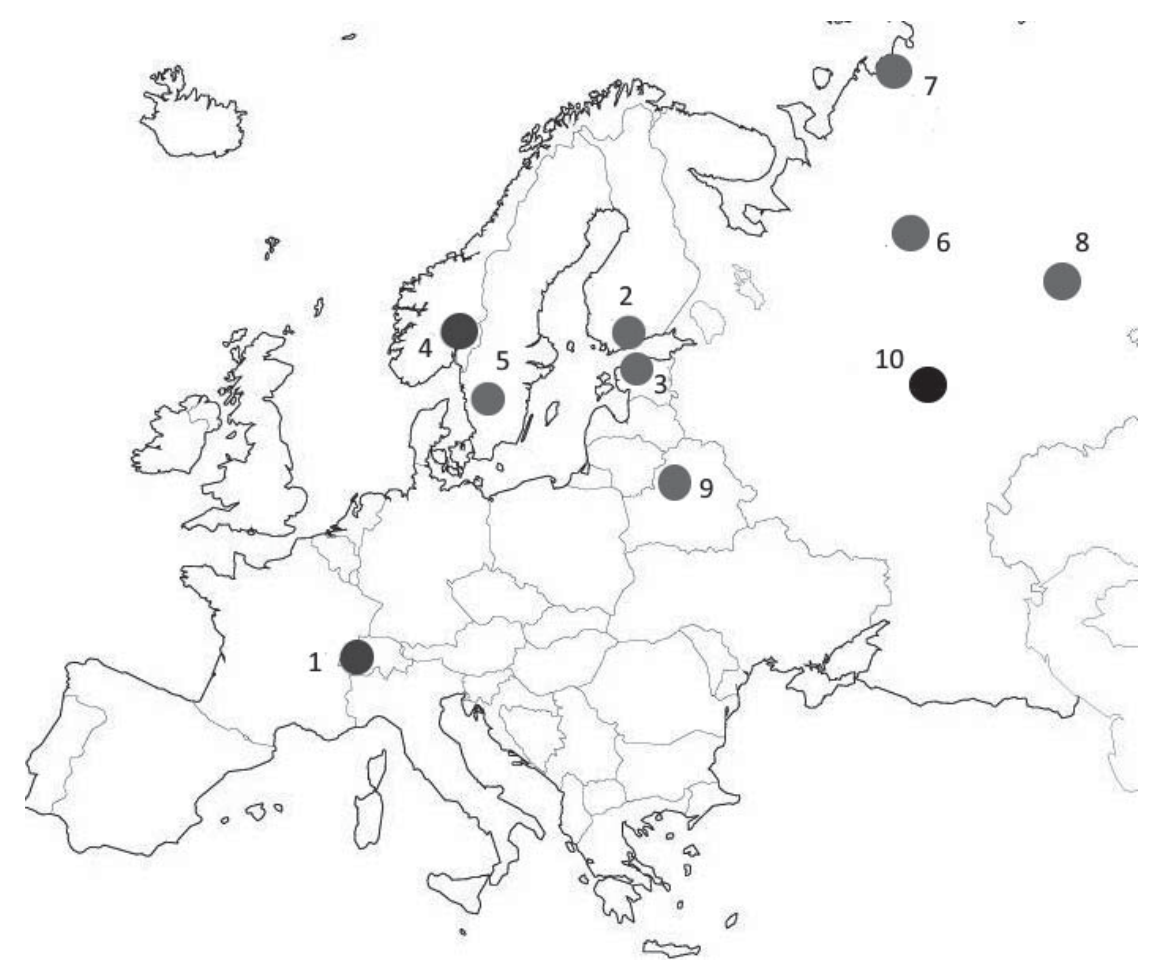

Fig. 1. Map of sample locations of examined specimens of A. crassa. Locality names are listed in Table 2. Number 1 and 4, group I; 10, Rybinsk reservoir; other numbers, group II.

Рис. 1. Карта мест сбора исследованных экземпляров A. crassa. Названия местообитаний перечислены в таблице 2. Номер 1 и 4 относятся к группе I, номер 10 - Рыбинское водохранилище, остальные номера относятся к группе II.

test (each character was compared between two populations, and then all populations were gathered in one matrix to point out the differences) (Kruskal, Wallis, 1952; Stephens, 1974). Measurements were performed with the help of an ocular micrometer under the microscope. Statistical analysis were performed with Statistica 7.0 and Past 3.20 softwares. Principal Component Analysis (PCA) plot was built in Past 3.20. All values were transformed to a standard normal distribution before plotting.

To carry out the phylogenetic analysis, 35 females of A. crassa from ten different populations were used (Table 1). Genomic DNA was extracted from animals preserved in $96 \%$ ethanol, following the protocols outlined in Walsh et al. (1991). Specifically, the bodies of each specimen were introduced into to $6 \%$ Chelex-100 solution (Sigma-Aldrich, St Louis, MO, USA) in bi-distilled water. Samples were spun for $30 \mathrm{~s}$ at $12.000 \mathrm{rpm}$. The mixture was incubated at $90{ }^{\circ} \mathrm{C}$ for $30 \mathrm{~min}$, then again spun for $30 \mathrm{~s}$ at $12.000 \mathrm{rpm}$. Samples were incubated at $90^{\circ} \mathrm{C}$ for $15 \mathrm{~min}$ and spun for $15 \mathrm{~s}$ at $12.000 \mathrm{rpm}$. Afterwards samples were stored at $20^{\circ} \mathrm{C}$ and amplified through PCR. In order to amplify the COI mtDNA gene, direct and reverse universal primers designed for invertebrates were used: COIH 2198(5'-TAAACTTCAGGGTGACCAAAAAATCA-3') and COIL 1490 (5'-GGTCAACAAATCATAAAGATATTGG-3') (Folmer, 1994). Additionally, special primers for zooplanktonZplankF1_t1(5'-TGTAAAACGA C G GCCA G T T C TA S W A A T CA T AARGATATTGG-3') and ZplankR1_t1 (5'CAGGAAACAGCTATGACTTCAGGGRTGRCCRAARAATCA3-') (Prosser, 2013) were used. The reaction mix consisted of $1 \mu \mathrm{L}(10$ 
Table 1. Sampling localities, number of specimens studied for phylogenetic and morphological analysis, and accession numbers in the GenBank of Attheyella crassa.

Таблица 1. Места сбора материала, количество изученных морфологически и филогенетически образцов и номера последовательностей Attheyella crassa в базе данных GenBank.

\begin{tabular}{|c|c|c|c|c|c|c|}
\hline No. & $\begin{array}{c}\text { Country, } \\
\text { area }\end{array}$ & $\begin{array}{c}\text { Locality } \\
\text { (water } \\
\text { body) }\end{array}$ & $\begin{array}{l}\text { Coor- } \\
\text { dinates }\end{array}$ & $\begin{array}{l}\text { Number } \\
\text { genetics }\end{array}$ & $\begin{array}{l}\text { specimens for } \\
\text { morphology }\end{array}$ & GenBank \\
\hline 1 & $\begin{array}{c}\text { Geneva, } \\
\text { Switzerland }\end{array}$ & $\begin{array}{c}\text { Lake } \\
\text { Geneva }\end{array}$ & $\begin{array}{c}46^{\circ} 27^{\prime} \mathrm{N} \\
06^{\circ} 31^{\prime} \mathrm{E}\end{array}$ & 3 & 6 & $\begin{array}{l}\text { MH477669- } \\
\text { MH477671 }\end{array}$ \\
\hline 2 & $\begin{array}{l}\text { Hämeenlinna, } \\
\text { Finland }\end{array}$ & $\begin{array}{c}\text { Lake } \\
\text { Pääjärvi }\end{array}$ & $\begin{array}{l}61^{\circ} 04^{\prime} \mathrm{N} \\
25^{\circ} 08^{\prime} \mathrm{E}\end{array}$ & 3 & 44 & $\begin{array}{l}\text { MH477643- } \\
\text { MH477645 }\end{array}$ \\
\hline 3 & $\begin{array}{l}\text { Tallinn, } \\
\text { Estonia }\end{array}$ & Creek Hiiu & $\begin{array}{l}59^{\circ} 38^{\prime} \mathrm{N} \\
24^{\circ} 67^{\prime} \mathrm{E}\end{array}$ & 1 & 3 & MH477651 \\
\hline 4 & Oslo, Norway & $\begin{array}{c}\text { Lake } \\
\text { Sognsvann }\end{array}$ & $\begin{array}{l}59^{\circ} 58^{\prime} \mathrm{N} \\
10^{\circ} 43^{\prime} \mathrm{E}\end{array}$ & 6 & 20 & $\begin{array}{c}\text { MH477663- } \\
\text { MH477668 }\end{array}$ \\
\hline 5 & Sweden & $\begin{array}{l}\text { Lake } \\
\text { Vänern }\end{array}$ & $\begin{array}{l}58^{\circ} 55^{\prime} \mathrm{N} \\
13^{\circ} 30^{\prime} \mathrm{E}\end{array}$ & 2 & 2 & $\begin{array}{l}\text { MH477652, } \\
\text { MH477653 }\end{array}$ \\
\hline 6 & $\begin{array}{l}\text { Komi } \\
\text { Republic, } \\
\text { Russia }\end{array}$ & $\begin{array}{l}\text { Nyuvchim } \\
\text { reservoir }\end{array}$ & $\begin{array}{l}61^{\circ} 39^{\prime} \mathrm{N} \\
50^{\circ} 74^{\prime} \mathrm{E}\end{array}$ & 3 & 5 & $\begin{array}{l}\text { MH477638- } \\
\text { MH477639 }\end{array}$ \\
\hline 7 & $\begin{array}{l}\text { Naryan-Mar, } \\
\text { Russia }\end{array}$ & $\begin{array}{l}\text { Pechora } \\
\text { River }\end{array}$ & $\begin{array}{l}68^{\circ} 18^{\prime} \mathrm{N} \\
54^{\circ} 22^{\prime} \mathrm{E}\end{array}$ & 1 & 1 & MH477650 \\
\hline 8 & $\begin{array}{l}\text { Udmurtia, } \\
\text { Russia }\end{array}$ & $\begin{array}{c}\text { Creek } \\
\text { Karkalai }\end{array}$ & $\begin{array}{l}56^{\circ} 98^{\prime} \mathrm{N} \\
52^{\circ} 40^{\prime} \mathrm{E}\end{array}$ & 2 & 3 & $\begin{array}{l}\text { MH477654, } \\
\text { MH477655 }\end{array}$ \\
\hline 9 & Belarus & $\begin{array}{l}\text { Lake } \\
\text { Narach }\end{array}$ & $\begin{array}{l}54^{\circ} 87^{\prime} \mathrm{N} \\
26^{\circ} 69^{\prime} \mathrm{E}\end{array}$ & 4 & 4 & $\begin{array}{l}\text { MH477646- } \\
\text { MH477649 }\end{array}$ \\
\hline 10 & Borok, Russia & $\begin{array}{l}\text { Rybinsk } \\
\text { reservoir }\end{array}$ & $\begin{array}{l}58^{\circ} 08^{\prime} \mathrm{N} \\
38^{\circ} 28^{\prime} \mathrm{E}\end{array}$ & 10 & 10 & $\begin{array}{l}\text { MH477640- } \\
\text { MH477642, } \\
\text { MH477656- } \\
\text { MH477662 }\end{array}$ \\
\hline
\end{tabular}

$\mu \mathrm{M})$ of direct and reverse primers each, $12 \mu \mathrm{L}$ of DreamTaq Hot Start PCR Master Mix (ThermoFisher Scientific), $9 \mu \mathrm{L}$ of water without nucleases (Ambition, United States) and $1 \mu \mathrm{L}$ of isolated DNA. Thermocycler conditions for PCR started with DNA denaturing at $95^{\circ} \mathrm{C}(60 \mathrm{~s})$, followed by 35 cycles of $30 \mathrm{~s}$ denaturing at $95^{\circ} \mathrm{C}, 30 \mathrm{~s}$ annealing at $50^{\circ} \mathrm{C}$, and $50 \mathrm{~s}$ extension at $72^{\circ} \mathrm{C}$, and then a final extension at $72^{\circ} \mathrm{C}$ for 7 $\min$ (Lee, 1999). PCR products were visualized by electrophoresis in $2 \%$ agarose gel in $1 \mathrm{x}$ triacetate buffer solution. A $100 \mathrm{bp}$ Ladder DNA marker (100 bp - 3000 bp) (ThermoFisher Scientific) was used as a marker for evaluation of the length of DNA fragments. To purify the obtained product, a set of ExoSap-IT PCR Product Clean-Up (Applied Biosystems) was applied. PCR products amplified with Folmer primers were sequenced with Folmer primers, while those amplified by zooplankton-specific primers were sequenced with M13F and M13R. Sequencing was carried out using the BigDye Terminator v3.1 (Life Technology) reagent kit on the ABI PRISM 310 Genetic Analyzer (Applied Biosystems, USA). In order to avoid errors in sequences, the bi-directional sequencing was used.

Nucleotide sequences were aligned with the algorithm CrustalW using the program package Geneious (version 7.0.6.) (Kearse et al., 2012). After comparing sequences obtained from the two above mentioned sets of primers, the length of the nucleotide sequences was $550 \mathrm{bp}$. Phylogenetic trees were also constructed in this program, using a Maximum Likelihood method with a high level of the bootstrap coefficient (1000 replications). Genetic distances were calculated using Tamura-Nei model in Mega 7.0. 

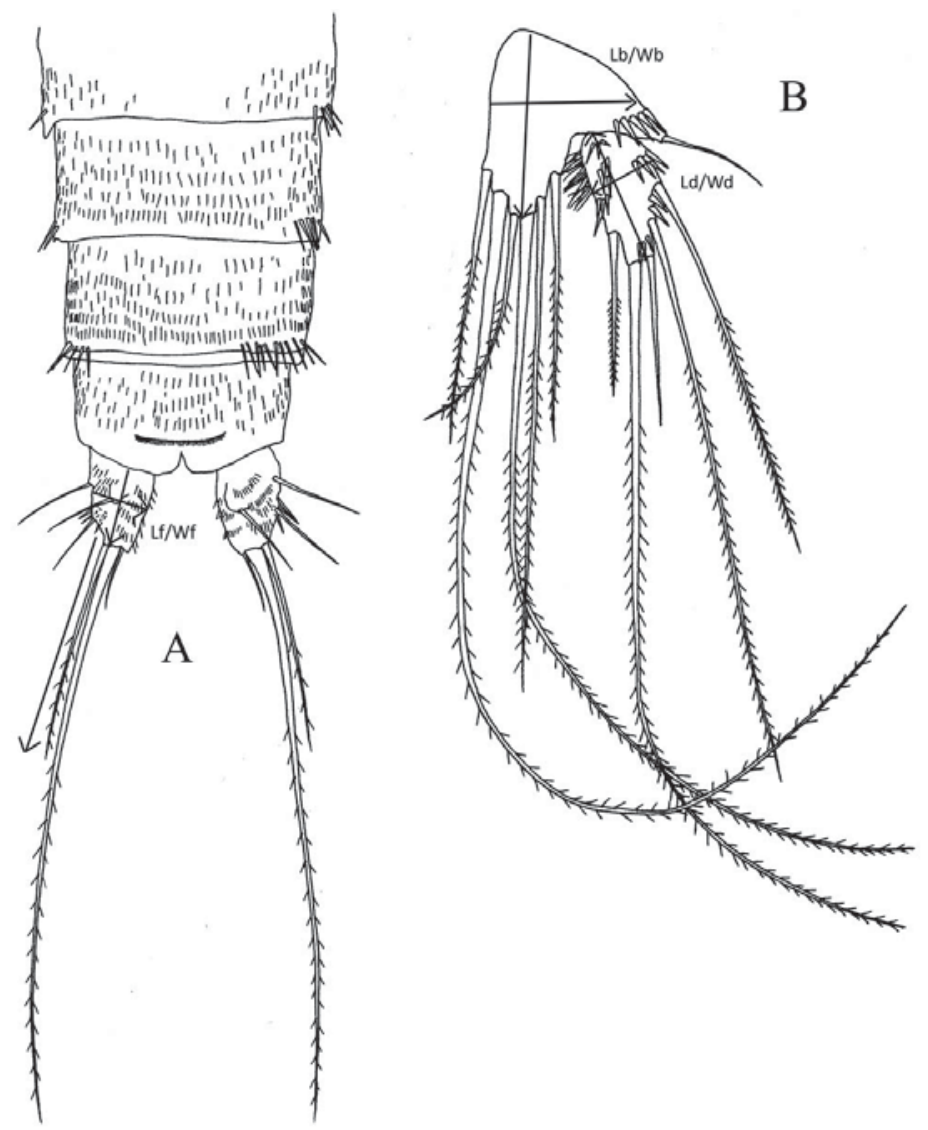

Fig. 2. Abdomen and caudal rami (A) and fifth pair of legs (B) of A. crassa. Arrows show measured morphological characters and indices. Drawings made by E.B. Fefilova.

Рис. 2. Абдомен и каудальные нити (А) и пятая пара ножек (B) гарпактициды A. crassa. Стрелки указывают на изученные морфологические признаки и индексы. Рисунки выполнены Е.Б. Фефиловой.

All sequences of $A$. crassa were registered in the GenBank under the accession numbers MH477638-MH477669. In addition, a sequence of Canthocamptus staphylinus (Jurine, 1820) (accession number KP974713) was included in the phylogenetic analysis. A sequence of Elaphoidella humphreysi Karanovic, 2006 (accession number JN039173) was used as the outgroup.

\section{Results}

\section{Morphological variability}

According to the main diagnostic features — segmentation and structure of antennules and antennae, structure of thoracic legs and form of caudal rami and anal operculum - all studied specimens correspond to the description of the species A. crassa, following Borutzky (1952, 1964) and Lang (1948). Among all measured morphological structures, the most significant variable characters $(p<0.05)$ were as follows: total body length, length of the seta $\mathrm{V}$ (= longest apical armament) of the caudal rami, length to width ratio of caudal rami (Lf/Wf), length to width ratio of exopod (distal segment) of the fifth pair of legs (Ld/Wd), and length to width ratio of basoendopod of the fifth pair of legs (Lb/Wb) (Fig. 2).

The mean values of measured morphological traits among populations are listed in Table 
Table 2. Mean values and standard deviation of variable morphological characters among the eight populations of $A$. crassa.

Таблица 2. Средние значения и стандартное отклонение вариабельных морфологических признаков среди восьми популяций A. crassa.

\section{Morphological characters}

\begin{tabular}{cccccc} 
Waterbody & $\begin{array}{c}\text { Body } \\
\text { length, } \mathbf{m m}\end{array}$ & $\begin{array}{c}\text { Caudal rami: seta V, } \\
\text { length, } \mathbf{m m}\end{array}$ & Lf/Wf & Ld/Wd & Lb/Wb \\
\hline Pääjärvi & $0.671 \pm 0.066$ & $0.372 \pm 0.039$ & $1.925 \pm 0.205$ & $2.014 \pm 0.074$ & $2.308 \pm 0.075$ \\
Geneva & $0.766 \pm 0.028$ & $0.403 \pm 0.071$ & $1.733 \pm 0.292$ & $2.510 \pm 0.790$ & $2.282 \pm 0.405$ \\
Vänern & $0.630 \pm 0.127$ & $0.440 \pm 0.014$ & $1.994 \pm 0.001$ & $2.181 \pm 0.001$ & $2.153 \pm 0.001$ \\
Sognsvann & $0.700 \pm 0.082$ & $0.416 \pm 0.052$ & $1.533 \pm 0.144$ & $2.470 \pm 0.241$ & $2.023 \pm 0.047$ \\
Hiiu & $0.810 \pm 0.018$ & $0.443 \pm 0.038$ & $2.159 \pm 0.155$ & $2.303 \pm 0.052$ & $2.153 \pm 0.001$ \\
Narach & $0.720 \pm 0.050$ & $0.415 \pm 0.035$ & $1.866 \pm 0.001$ & $1.923 \pm 0.001$ & $2.307 \pm 0.001$ \\
Karkolai & $0.738 \pm 0.047$ & $0.393 \pm 0.041$ & $2.236 \pm 0.205$ & $2.666 \pm 0.135$ & $2.000 \pm 0.001$ \\
Rybinsk & $0.635 \pm 0.035$ & $0.385 \pm 0.021$ & $2.029 \pm 0.041$ & $2.588 \pm 0.001$ & $2.153 \pm 0.001$ \\
reservoir & & & & & \\
\hline
\end{tabular}

Lf and Wf - length and wide of caudal rami respectively; Ld and Wd - length and wide of exopod of fifth leg, respectively; $\mathrm{Lb}$ and $\mathrm{Wb}$ - length and wide of basipod of fifth leg, respectively.

2. The body length of adult females varied from 0.6 to $0.828 \mathrm{~mm}$. The smallest specimen was found in Lake Pääjärvi, the largest one in the creek Hiiu. The length of seta V of the caudal rami varied from 0.3 (Lake Pääjärvi) to 0.52 $\mathrm{mm}$ (Lake Sognsvann). The ratio Lf/Wf changed from 1.375 (Lake Sognsvann) to 2.365 (Lake Pääjärvi). The ratio $\mathrm{Ld} / \mathrm{Wd}$ varied from 1.69 (Lake Geneva) to 2.72 (Lake Pääjärvi). The ratio $\mathrm{Lb} / \mathrm{Wb}$ changed from 1.92 (Lake Narach) to 3.35 (Lake Geneva).

As a result of clustering of females of $A$. crassa on the PCA plot (Fig. 3, Table 3), two main groups of populations were found. The first group (I) includes populations from the lakes Pääjärvi (Finland), Vänern (Sweden), Narach (Belarus), Rybinsk reservoir (Borok, Russia) and creeks Karkalai (Udmurtia, Russia) and Hiiu (Estonia). The second group (II) includes specimens from lakes Sognsvann (Norway) and Geneva (Switzerland).

\section{Phylogenetic variability}

Thirty-five original COI sequences of $A$. crassa contained 67 polymorphic sites, where 65 showed informative parsimony. Thirteen haplotypes were identified, the total haplotype diversity was 0.882 . The total number of mutation was 67.

All sequences formed two main clades in the phylogenetic tree constructed with the Maximum Likelihood Method (Fig. 4). The first clade (I) includes sequences of specimens collected from the lakes Pääjärvi (Finland), Vänern (Sweden), Narach (Belarus), Nyuvchim (Komi Republic, Russia) and Rybinsk reservoirs (Borok), the creeks Hiiu (Estonia) and Karkalai (Udmurtia, Russia), and the river Pechora (Naryan-Mar, Russia). The second clade (II) includes sequences of specimens from the type locality of the species Lake Sognsvann (Norway), Lake Geneva (Switzerland) and Rybinsk reservoirs (Borok, Russia). The genetic distances between these two clades were $19.6 \%$ and between populations of A. crassa and C. staphylinus (both belonging to the family Canthocamptidae) $-27.2 \%$. The genetic distances between populations inside the clades ranged from 0.5 to $3 \%$.

\section{Discussion}

The order Harpacticoida and particularly the family Canthocamptidae show significant 


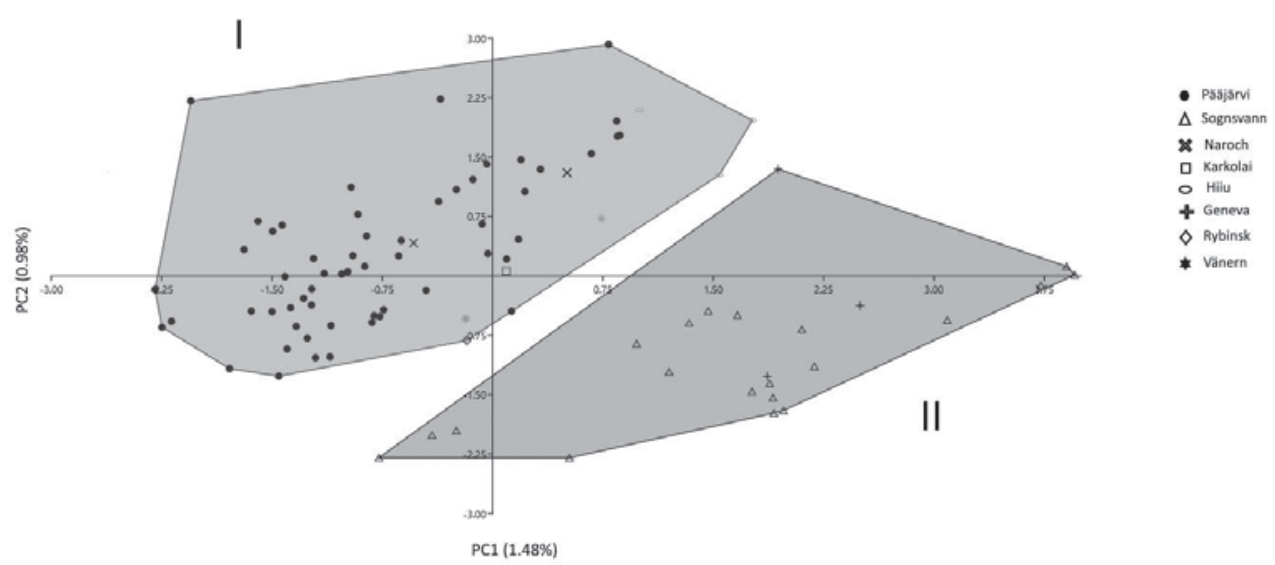

Fig. 3. Principal component analysis of morphological traits. I, II - groups of populations of A. crassa, similar to the clades in the phylogenetic tree (Fig. 4). PC1 and PC2 are plotted on x- and y-axes. The percentage of variation explained by the plotted principal coordinates is indicated on the axes.

Рис. 3. График, построенный на основе Метода Главных Компонент. I, II — группы популяций $A$. crassa, соответствующие кладам на филогенетическом древе (рис. 4). ГК1 и ГК2 обозначены вдоль осей абсцисс и ординат. Коэффициент вариации (\%) построенного графика указан рядом с осями.

Table 3. Factor loadings on components based on PCA plot (Fig. 3).

Таблица 3. Факторные нагрузки к графику, построенному методом главных компонент (рис. 3).

\begin{tabular}{cccccc}
\hline Character & PC 1 & PC 2 & PC 3 & PC 4 & PC 5 \\
\hline Body length & 0.09515 & 0.016687 & 0.0087835 & 0.89285 & 0.43973 \\
Apical spine & -0.0047163 & -0.0041321 & -0.04123 & 0.4415 & 0.89625 \\
$\mathrm{Lf} / \mathrm{Wf}$ & 0.40324 & 0.90113 & 0.14316 & -0.048947 & 0.024227 \\
$\mathrm{Ld} / \mathrm{Wd}$ & 0.90901 & -0.3985 & 0.062073 & -0.06987 & 0.039558 \\
$\mathrm{Lb} / \mathrm{Wb}$ & 0.0034898 & 0.15338 & 0.98629 & 0.023923 & 0.034741 \\
\hline
\end{tabular}

morphological diversity (Wells, 2007). The canthocamptid copepod A. crassa is considered to be a morphologically stable species across its distributional range (Borutzky, 1952, 1964). However, its subspecies Attheyella crassa thracica Michailova-Neikova, 1966 described from Bulgaria has been accepted (Walter, Boxshall, 2018) based on the different shape of the caudal rami and the particular bend of the longest apical armament (seta V). A second subspecies Attheyella crassa schmeili Gagern, 1938 collected in Germany (Harz region), with minor morphological differences on the caudal rami and the size of setae on the legs (compared with
Scandinavian populations of $A$. crassa), caused Lang (1948) to consider it as not valid.

The present study revealed variability of several morphological traits among populations of $A$. crassa. The morphology of the caudal rami and length of its longest seta (seta V), the body length as well as the morphology of basoendopod and exopod of the fifth pair of legs, showed significant fluctuations among the examined populations. For example, the caudal rami of specimens from group I, which includes populations from the lakes Geneva and Sognsvann, were smaller compared with populations of the localities of group II (Table 2). 


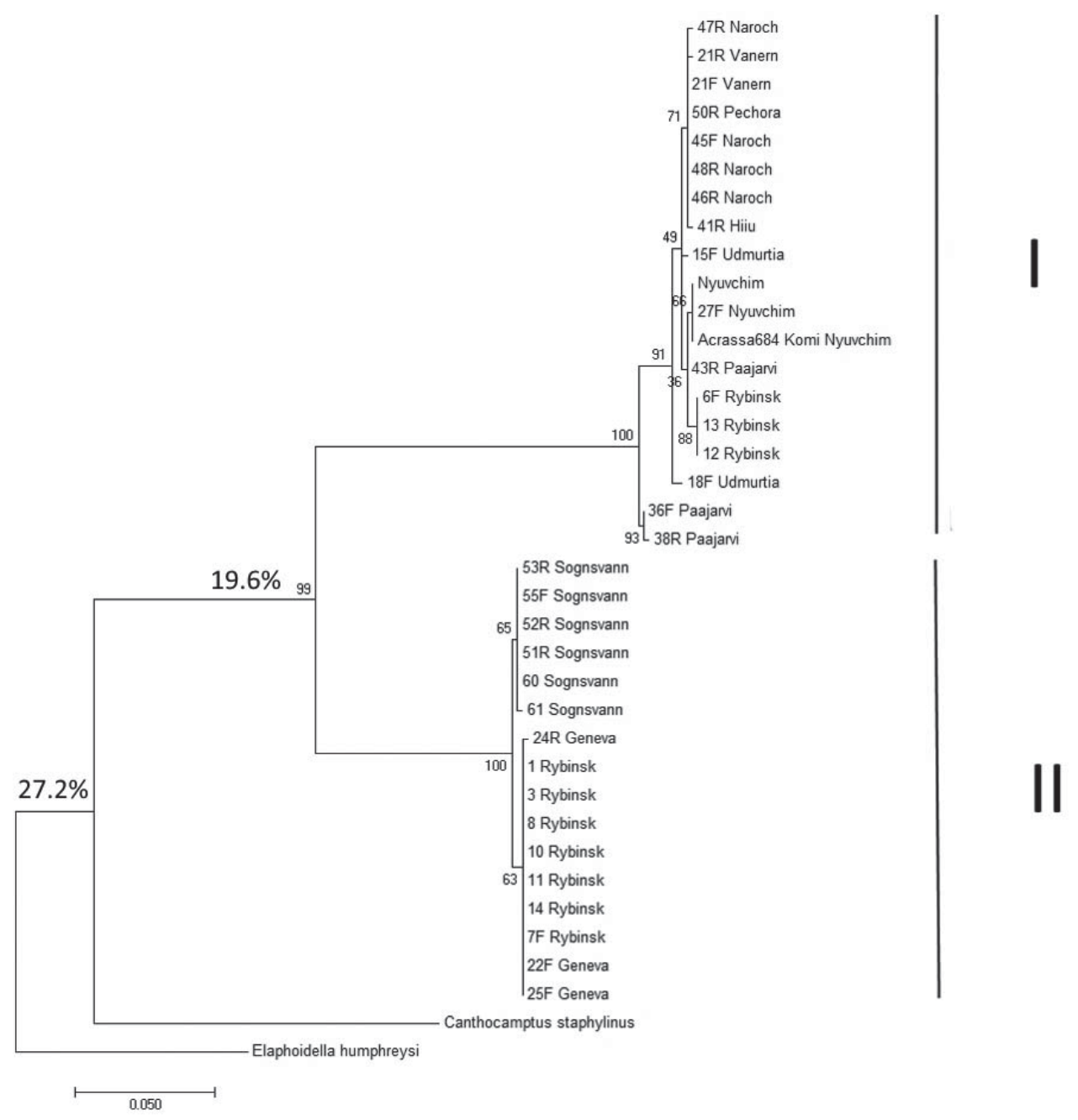

Fig. 4. Phylogenetic tree of the relationship between populations of A. crassa based on data from mitochondrial cytochrome oxidase subunit I (COI) region by the maximum likelihood method. Numbers beside nodes indicate bootstrap values and genetic distances (in \%). A sequence of Elaphoidella humpreysi Karanovic, 2006 from NCBI was used as outgroup (accession number JN039173). I, II — clades.

Рис. 4. Филогенетическое дерево, построенное методом ML на основе сравнения нуклеотидных последовательностей участков гена COI гарпактикоид вида Attheyella crassa. В узлах указаны значения бутстреп-поддержки и генетические дистанции (\%). В качестве внешней группы использована последовательность гена COІ гарпактикоиды Elaphoidella humpreysi Karanovic, 2006 (JN039173). I, II - клады.

The genetic divergence (19.6\%) between clades (Fig. 4), when compared to groups on the PCA plot (Fig. 3), confirmed heterogeneity among the populations. Similar genetic variability revealing the existence of several cryptic forms has been found in other studies of popula- tion structure based on molecular-genetic analysis of harpacticoids. For instance, phylogenetic and phylogeographic structure among populations of the marine harpacticoid Tigriopus californicus (Baker, 1912) showed divergences of mtDNA that often exceeded 20\% (Burton et 
al., 2007; Willet, Ladner, 2009). In another marine harpacticoid Nannopus palustris Brady, 1880 even higher values have been found: the genetic distances of mtDNA reached up to $78 \%$ between populations and allowed to separate several cryptic forms (Garlitzka et al., 2012).

Our previous investigation of interpopulational diversity in C. staphylinus also showed polymorphism. It was expressed in genetic distances that reached up to $25 \%$ between geographically separated populations (Kochanova et al., 2018). High levels of intra- and interspecific divergence seem to be a widespread phenomenon among members of the order Harpacticoida (Schizas et al., 1999; Easton et al., 2010). In freshwater copepod species, the observed moleculargenetic divergence can be the result of founder and bottleneck effects accompanied by limited gene flow between populations, even in adjacent habitats (Bucklin et al., 1998).

Therefore we can conclude that in the studied populations of $A$. crassa there are two morphologically and genetically distant forms, which should be considered as different taxonomical units at the subspecies level. The division of clades in the phylogenetic tree (Fig. 4) is identical to the separation of groups in the PCA plot (Fig. 3), except for the population from Rybinsk reservoir, which was present in both clades. We can assume that in this waterbody there are two genetic forms with similar morphology.

We recommend further study of additional material (particularly on populations of $A$. cras$s a$ from southern Europe, northern Africa and non-Russian Asia) together with the analysis of nuclear genes, in order to clarify the taxonomy of this species. In this way, the subspecies with predominantly northern distribution in the Palearctic Region could be described.

\section{Acknowledgments}

We are very grateful to Natalia M. Sukhikh (Saint Petersburg), Maria A. Baturina (Syktyvkar) and Inta Dimante-Deimantovica (Oslo) for provided harpacticoid samples from Lake Geneva and the creek Karkalai, Lake Narach and Lake Sognsvann. In addition, we are thankful to Elena B. Fefilova (Syktyvkar) for the morphological drawings and her suggestions to improve the manuscript and to Kay Van Damme (Ghent) for linguistic corrections of earlier draft. Our research was supported by the Russian Fund of Basic Researches grants No. 17-0400027 and 18-44-110017, within the Complex UB RAS Program No. AAAA-A18118011390005-9.

\section{References}

Borutzky E.V. 1952. [Freshwater Harpacticoida] // Fauna SSSR. Rakoobraznye. Vol.3. Iss.4. Moscow: AN SSSR Publ. P.1-424 [in Russian].

Borutzky E.V. 1964. Fauna of USSR. Crustacea. Freshwater Harpacticoida: 396 pp. (Israel Program for Scientific Translations, Jerusalem).

Brady G.S. 1880. A monograph of the free and semiparasitic Copepoda of the British Islands. Vol. II // The Ray Society Series 55. London, UK: Ray Society. 183 p.

Bucklin A., Caudill C.C., Guarnieri M. 1998. Population genetics and phylogeny of planktonic copepods // K.C. Cooksey (ed.). Molecular Approaches to the Study of the Ocean. London, UK: Chapman \& Hall. P.303-317.

Burton R.S., Byrne R.J., Rawson P.D. 2007. Three divergent mitochondrial genomes from California populations of the copepod Tigriopus californicus // Gene. Vol.403. P.53-59.

Dayrat B. 2005. Towards integrative taxonomy // Biol. J. Linn. Soc. Vol.85. No.3. P.407-417.

Defaye D., Dussart N. 2011. World directory of Crustacea Copepoda of inland waters, II- Harpacticoides. Paris, France: Editions N. Boubée \& Cie. 450 p.

Dussart B.H. 1967. Les Copépodes des Eaux Continentales d'EuropeOccidentale. Tome I: Calanoides et Harpacticoides. Paris: Ed. N. Boubée \& Cie. 500 p.

Easton E.E., Thistle D., Spears T. 2010. Species boundaries in Zausodes-complex species (Copepoda: Harpacticoida: Harpacticidae) from the north-eastern Gulf of Mexico // Invertebrate Syst. Vol.24. No.3. P.258270.

Enckell P.H. 1980. Kraftdjur (faltfauna). [Signum], Lund, Sweden. 420 p. [in Swedish]

Folmer O., Black M., Hoeh W., Lutz R., Vriyenhoek R. 1994. DNA primers for amplification of mitochondrial cytochrome c oxidase subunit I from diverse metazoan invertebrates // Mol. Mar. Biol. Biotechnol. Vol.3. P.294-299.

Gagern E. 1938. Harpacticoida des Harzes // Zoologischer Anzeiger. Bd.124. H.7. S.175-182.

Garcia-Paris M., Alcobendas M., Buckley D., Wake D.B. 2003. Dispersal of viviparity across contact zones in Iberian populations of fire salamanders (Salamandra) inferred from discordance of genetic and morphological traits // Evolution. Vol.57. P.129-143. 
Gardeström J., Dahl U., Kotsalainen O., Maxson A., Elfwing T., Grahn M., Bengtsson B.E., Breitholtz M. 2008. Evidence of population genetic effects of longterm exposure to contaminated sediments - a multiendpoint study with copepods // Aquat. Toxicol. Vol.86. P.426-436.

Garlitzka L., Neretina T., Shepetov D., Mugue N., Bagulei J., Azovsky A. 2012. Cryptic diversity of the 'cosmopolitan' harpacticoid copepod Nannopus palustris: genetic and morphological evidence // Mol. Ecol. Vol.21. P.5336-5347.

Gaviria, S., Defaye D. 2015.Description of Elaphoidella paramuna n.sp. (Canthocamptidae), a new harpacticoid copepod from Colombia // Crustaceana. Vol.88. No.9. P.1003-1029.

Huys R., Suárez-Morales E., Serrano-Sánchez M.L., Centeno-García E., Vega F.J. 2016. Early Miocene amber inclusions from Mexico reveal antiquity of mangrove associated copepods // Sci. Reports. Vol.6. https:// www.nature.com/articles/srep34872.

Jurine L. 1820. Histoire des Monocles, qui se trouvent aux environs de Genève. Genève et Paris. 258 p.

Karanovic T., McRae J. 2013. The genus Schizopera (Copepoda: Harpacticoida) in the Pilbara region of Western Australia, with description of a new species and its molecular and morphological affinities // Rec. Western Austral. Mus. Vol.28. P.119-140.

Karanovic T. 2006. Subterranean copepods (Crustacea, Copepoda) from the Pilbara region in Western Australia// Rec. Western Austral. Mus., Suppl.. Vol.70. P.1239.

Kearse M., Moir R., Wilson A., Stones-Havas S., Cheung M., Sturrock S., Buxton S., Cooper A., Markowitz S., Duran C., Thierer T., Ashton B., Mentjies P., Drummond A. 2012. Geneious Basic: an integrated and extendable desktop software platform for the organization and analysis of sequence data // Bioinformatics. Vol.28. No.12. P.1647-1649.

Kochanova E.S., Fefilova E.B., Sukhikh N.M., Velegzhaninov I.O., Shadrin D.M., PylinaYa.I., Alekseev V.R. 2018. Morphological and Molecular-Genetic Polymorphism of Canthocamptus staphylinus Jurine (Harpacticoida, Copepoda, Crustacea) // Inland Water Biol. Vol.11. No.2. P.120-132.

Kruskal W., Wallis A.W. 1952. Use of ranks in onecriterion variance analysis // J. Amer. Statist. Assoc. Vol.47. No.260. P.583-621.

Lang K. 1948. Monographie der Harpacticiden. Lund: Hiken Ohlsson. Bd.1-2. 1682 S.
Lee C.E. 1999. Rapid and repeated invasions of fresh water by the copepod Eurytemora affinis // Evolution. Vol.53. P.1423-1434.

Masta S., Maddison W.P. 2002. Sexual selection driving diversification in jumping spiders // Proc. Nat. Acad. Sci. USA. Vol.99. P.4442-4447.

Michailova-Neikova M. 1966. [Harpacticoida from the Thracian lowland] // Fauna Trakiya. Vol.3. P.201216 [in Bulgarian].

Prosser S., Martínez-Arce A., Elías-Gutiérrez M. 2013. A new set of primers for COI amplification from freshwater microcrustaceans // Mol. Ecol. Resources. Vol.13. P.1151-1155.

Sars G.O. 1863. Oversigt af de indenlandske Ferskvandcopepoder. Forhandlinger i Videnskabs-Selskabet i Christiania Aar. P.212-262.

Schizas N.V., Street G.T., Coull B.C., Chandler G.T., Quattro J.M. 1999. Molecular population structure of the marine benthic copepod Microarthridion littorale along the southeastern and Gulf coasts of the USA // Marine Biol. Vol.135. P.399-405.

Stephens M.A. 1974. EDF Statistics for Goodness of Fit and Some Comparisons // J. Amer. Statist. Assoc. Vol.69. No.347. P.730-737.

Turesson E.U., Stiernstrom S., Minten J., Adolfsson-Erici M., Bengtsson B., Breitholtz M. 2007. Development and reproduction of the freshwater harpacticoid copepod Attheyella crassa for assessing sediment-associated toxicity // Aquat. Toxicol. Vol.83. P.180-189.

Walsh P.S., Metzger D.A, Higuchi R. 1991. Chelex 100 as a medium for simple extraction of DNA for PCRbased typing from forensic material // Biotechniques. Vol.10. P.506-513.

Walter T.C., Boxshall G. 2018. World of Copepods database. A. crassa (Sars G.O., 1862). Accessed through: World Register of Marine Species at: http:// marinespecies.org/aphia.php? $\mathrm{p}=$ taxdetails $\& \mathrm{id}=$ 357324 on $2018-06-21$

Wells J.B.J. 2007. An annotated checklist and keys to the species of Copepoda Harpacticoida (Crustacea) // Zootaxa. Vol.1568. P.1-872.

Willett C.S., Ladner J.T. 2009. Investigations of fine-scale phylogeography in Tigriopus californicus reveal historical patterns of population divergence // BMC Evol. Vol.9. P.131-139.

Responsible editor A.A. Kotov 